\title{
SISTEM PENDUKUNG KEPUTUSAN PEMBERIAN REKOMENDASI PESERTA BIDIKMISI DENGAN METODE ANALYTICAL HIERARCHY PROCESS

\author{
Widya Lelisa Army ${ }^{1)}$ \\ ${ }^{1}$ Sistem Informasi, STMIK “AMIKBANDUNG”, Bandung, Jawa Barat \\ email: widya@stmik-amikbandung.ac.id
}

\begin{abstract}
Abstrak
Penelitian yang dilakukan pada SMA Negeri 12 Padang di dalam menentukan rekomendasi pada bakal calon peserta bidikmisi secara konvensional sehingga menghasilkan calon pesertayang tidak sesuai maka dari itu dibuatlah Sistem Penunjang Keputusan di dalam Bidikmisi dengan metode Analytical Hierarchy Process (AHP) dan dibantu bahasa pemograman JAVA dengan database MySQL. Jadi dibuatlah aplikasi Sistem pendukung Keputusan yang dapat membantu pihak sekolah SMAN 12 Padang dalam merekomendasikan siswa yang berhak, berkompeten dan akurat dalam mengikuti program bidikmisi dengan hasil keputusan yang mutlak.
\end{abstract}

Kata Kunci: Sistem Penunjang Keputusan, AHP, Rekomendasi, Java, MySQL

\section{PENDAHULUAN}

\subsection{Latar Belakang}

Perkembangan teknologi saat ini semakin maju dan berkembang semakin pesat, khususnya dibidang informasi. Seiring dengan perkembangannya masyarakat dituntut untuk bisa beradaptasi dengan kondisi dari perkembangan teknologi tersebut. Dengan adanya perkembangan teknologi saat ini, sehingga dapat mempermudah segala aktifitas yang dilakukan manusia.Dahulu, orang menulis menggunakan alat tulis seperti pena atau pun pensil. Sekarang ini, menulis manual dapat digantikan dengan menggunakan komputer. Cukup dengan menekankan papan ketik, huruf atau angka yang diinginkan akan muncul di layar. Adapun disetiap lembaga pendidikan khususnya dalam penerimaan beasiswa (Eniyati S, 2011).

Pengembangan aplikasi sistem sudah meliputi berbagai bidang salah satunya untuk membuat sistem pendukung keputusan untuk seleksi calon siswa peserta bidikmisi. Bidikmisi merupakan salah satu program pemerintah melalui Departemen Pendidikan Nasional yang bertujuan untuk memberikan penghargaan atau dukungan dana terhadap mereka yang berprestasi. Bidikmisi merupakan bantuan pendidikan yang diberikan pemerintah bagi mereka yang memiliki potensi tingggi namun tidak memiliki finansial yang mencukupi untuk melanjutkan ke jenjangperguruan tinggi. Berbagai jenis beasiswa dan atau bantuan biaya pendidikan baik oleh pemerintah pusat, pemerintah daerah maupun dari dunia usaha atau industri sebenarnya sudah banyak diluncurkan. Akan tetapi bantuan yang diberikan relatif belum dapat memenuhi kebutuhan studi, jumlah sasaran dan belum menjamin keberlangsungan studi mahasiswa hingga selesai(Rahma W. et al, 2014).

Pemerintah melalui Direktorat Jenderal Pembelajaran dan Kemahasiswaan, Kementerian Riset Teknologi dan Pendidikan Tinggi mulai tahun 2010 meluncurkan Program Bantuan Biaya Pendidikan Bidikmisi yaitu bantuan biaya pendidikan bagi calon mahasiswa tidak mampu secara ekonomi dan memiliki potensi akademik baik untuk menempuh pendidikan di perguruan tinggi pada program studi unggulan sampai lulus tepat waktu (Rohayani W. et al, 2014).

$\underline{\text { https://ejournal.stmikgici.ac.id/ }}$ STMIK GICI 


\begin{abstract}
SMA Negeri 12 Padang merupakan sekolah yang selalu mendaftarkan siswanya setiap tahun untuk mengikuti bakal calon peserta bidikmisi.Dari pengalaman beberapa tahun yang telah dilakukan dalam seleksi pemilihan bidikmisi siswa masih terdapat beberapa permasalahan yaitu diantaranya pemilihan yang masih dilakukan secara manual membuat tidak efektif nya hasil yang diperoleh ini sangatlah merugikan siswa, serta tidak semua siswa yang diikutkan dalam seleksi bakal calon penerimaan bidikmisi hanya dipilih begitu saja (PardiJ, 2016).
\end{abstract}

Sistem Pendukung Keputusan adalah sistem yang berbasis komputer yang dapat membantu pengambilan keputusan untuk memecahkan masalah tertentu dengan memanfaatkan data dan model tertentu. Pada dasarnya SPK merupakan pengembangan lebih lanjut dari Sistem Informasi Manajemen terkomputerisasi yang dirancang sedemikian rupa sehingga bersifat interaktif dengan pemakainya. Interaktif dengan tujuan untuk memudahkan integrasi antara berbagai komponen dalam proses pengambilan keputusan seperti prosedur, kebijakan, analisis, pengalaman dan wawasan manajer untuk mengambil keputusan yang lebih baik (Aldo, 2019).

Dari permasalahan diatas maka perlu dirancang sistem pendukung keputusan yang diharapkan membantu dalam pengambilan keputusan untuk mendapatkan informasi yang tepat dalam penyeleksian siswa yang akan menerima bantuan bidikmisi dengan metode Analytical Hierarchy Process (AHP) sehingga memberikan alternatif terbaik dari kriteria yang sudah ditentukan.

(Eko D. et al,2014)

JURSIMA

Jurnal Sistem Informasi dan Manajemen

\subsection{Batasan Masalah}

Agar lebih jelas dan terarahnya pembahasan suatu topik yang dibahas, maka penulis perlu melakukan pembatasan masalah dalam pembahasan sebagai berikut:

1. Studi kasus dilakukan di SMA Negeri 12 Padang.

2. Program aplikasi ini hanya menyeleksi calon peserta bidikmisi yang didasarkan dari kriteria yang telah ditentukan.

3. Proses perhitugan menggunakan metode Analytical Hierarchy Process dengan bahasa pemrograman Java dan didukung dengan database MySQL.

\subsection{Perumusan Masalah}

Berdasarkan uraian dari latar belakang diatas, maka penelitian ini dapat dirumuskan masalahnya yaitu:

1. Bagaimana sistem pendukung keputusan yang dibangun dapat membantu pihak sekolah dalam menghasilkan keputusan yang mutlak?

2. Bagaimana menentukan kriteria dan alternatif apa saja yang diperlukan didalam pengambilan keputusan pemberian?

3. rekomendasi peserta bidikmisi dari masing-masing kriteria yang diujikan?

4. Bagaimana penerapan metode Analytical Hierarchy Process dalam pemberian rekomendasi calon peserta bidikmisi pada SMA Negeri 12 Padang?

\subsection{Tujuan Penelitian}

Adapun tujuan dari penelitian ini adalah:

1. Untuk membantu pihak sekolah dalam melakukan penyeleksian

https://ejournal.stmikgici.ac.id/ STMIK GICI 
calon peserta bidikimisi dengan mengembangkan suatu aplikasi sistem pendukung keputusan.

2. Menerapkan metode Analytical Hierarchy Process yang digunakan menentukan calon peserta bidikmisi SMA Negeri 12 Padang.

3. Merancang program aplikasi untuk sistem pendukung keputusan pemilihan bakal calon peserta bidikmisi serta menguji aplikasi dengan metode analytical hierarchy process (AHP).

\section{METODE PENELITIAN}

\subsection{Analisa Sistem}

Dalam mengatasi setiap permasalahan, sebelum menuju ke sasaran atau tujuan yang diinginkan, maka perlu dilakukan analisa terhadap permasalahan yang sebenarnya. Analisa sistem dapat didefenisikan sebagai penguraian dari suatu sistem yang utuh ke dalam bagian komponennya dengan maksud untuk mengidentifikasi dan mengevaluasi permasalahan, hambatan yang terjadi dan kebutuhan yang diharapkan sehingga dapat diusulkan perbaikannya. Karena dengan dilakukannya analisa sistem akan dapat memberikan kemudahan di dalam perancangan dan pembangunan terhadap sistem yang akan dibangun.

Dengan merencanakan perancangan terhadap sistem penunjang keputusan yang akan dibangun diharapkan dapat meminimalisasi masalah yang terjadi pada sistem yang akan dibangun.Untuk itu perlu dianalisa secara ringkas tentang bagaimana prosedur dari aliran sistem informasi datanya.

Tujuan dari analisis sistem ini adalah untuk mengetahui bagaimana tingkat keefisienan user dari segi waktu dan biaya dan bagaimana sistem dapat memberikan informasi kepada user .

\subsection{Aliran Sistem Informasi}

Aliran Sistem Informasi yang sedangberjalan

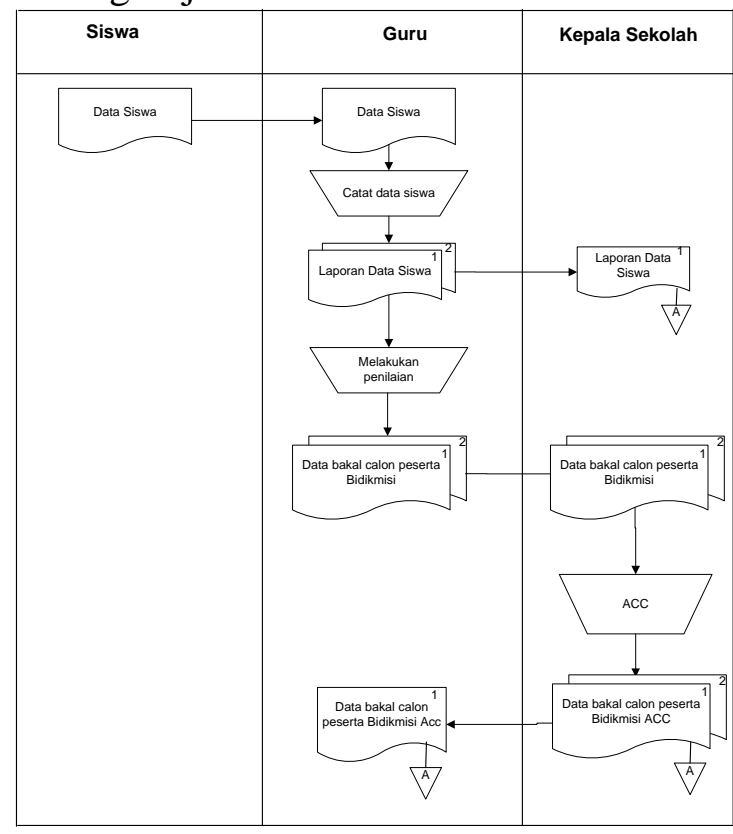

\section{Gambar 2.1 Aliran Sistem Informasi}

\subsection{Analisa Input}

Input dari sistem penunjang keputusan merupakan dokumen yang digunakan dalam proses seleksi bakal calon peserta bidikmisidiantaranya data-data bakal calon peserta bidikmisi (siswa) dan data kriteria penilaian. Data-data ini yang nantinya akan diolah dalam merancang Sistem Penunjang Keputusan seleksi bakal calon peserta bidikmisi.

\subsection{Analisa Proses}

Analisa proses merupakan analisa yang dilakukan terhadap proses dalam sistem informasi penunjang keputusan seleksi bakal calon peserta bidikmisi. Adapun proses-proses yang terjadi dalam

\section{https://ejournal.stmikgici.ac.id/} STMIK GICI 
sistem informasi seleksi bakal calon peserta bidikmisi adalah sebagai berikut:

1. Meproses data siswa bakal calon peserta bidikmisi.

2. SMA NEGERI 12 PADANG memberikan penilaian berdasarkan kriteria-kriteria yang telah ditentukan.

3. Menggunakan metode Analytical Hierarhcy Process (AHP).

\subsection{Analisa Output}

Berdasarkan analisa yang dilakukan terhadap output sistem serta kebutuhan sistem pada sistem informasi penunjang keputusan menjelaskan bahwa penggunaan teknologi informasi oleh SMA NEGERI 12 PADANG dalam melakukan seleksi bakal calon peserta bidikmisi masih belum optimal. Berdasarkan analisa input yang akan diproses maka output yang akan dihasilkan oleh sistem penunjan keputusan SMA NEGERI 12 PADANG adalah daftar rangking penilaian bakal calon peserta bidikmisi yang nantinya akan digunakan sebagai bahan untuk mengambil keputusan menentukan bakal calon peserta bidikmisi.

\subsection{Membangun Data Analisis Analytical Hierarhcy Process (AHP)}

Analisa AHP terdiri dari beberapa tahap yaitu dengan menentukan kriteria dan bobot penilaian. Dalam melakukan seleksi bakal calon peserta bidikmisi SMA NEGERI 12 PADANG menerapkan beberapa kriteria dalam penilaian. Adapun kriteria-kriteria penilaian yang diterapkan oleh SMA NEGERI 12 PADANG dapat dilihat pada Tabel 2.1
Tabel 2.1 Kriteria

\begin{tabular}{|l|l|l|}
\hline No. & Kode & Kriteria \\
\hline 1 & K001 & Tahun Lulus \\
\hline 2 & K002 & Penghasilan Ortu \\
\hline 3 & K003 & Jumlah Saudara \\
\hline 4 & K004 & Tanggungan Orang Tua \\
\hline 5 & K005 & Pendidikan Orang tua \\
\hline 6 & K006 & Prestasi Akademik \\
\hline
\end{tabular}

\subsection{Aliran Sistem Informasi (ASI) Baru}

Bagian ini merupakan kerangka dasar yang ditunjukan sebagai bahan usulan untuk mengembangkan sistem yang baru. Sistem yang baru ini akan memperbaiki kerja sistem pengolahan data tanpa mengganggu stabilitas sistem. Adapun Aliran Sistem Informasi (ASI) Baru dapat dilihat pada Gambar 2.2

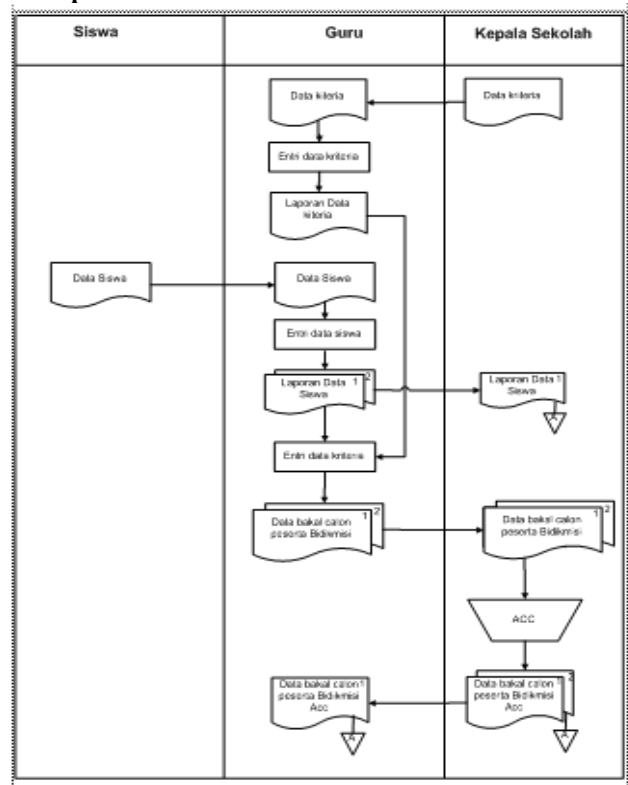

Gambar 2.2 Aliran Sistem Informasi Baru

\subsection{Perhitungan Metode AHP}

A. Menentukan Prioritas Kriteria

Langkah 1: Analisis berpasangan untuk dilakukan antar semua criteria dengan skor kompromi seperti ditunjukkan Tabel 2.2 


Tabel 2.2 Matrik Berpasangan
\begin{tabular}{|l|c|c|c|c|c|c|}
\hline Kriteria & K1 & K2 & K3 & K4 & K5 & K6 \\
\hline K1 & 1.00 & 5.00 & 5.00 & 5.00 & 3.00 & 3.00 \\
\hline K2 & 0.20 & 1.00 & 1.00 & 1.00 & 0.33 & 0.33 \\
\hline K3 & 0.20 & 1.00 & 1.00 & 1.00 & 0.33 & 0.33 \\
\hline K4 & 0.20 & 1.00 & 1.00 & 1.00 & 0.33 & 0.33 \\
\hline K5 & 0.33 & 3.00 & 3.00 & 3.00 & 1.00 & 1.00 \\
\hline K6 & 0.33 & 3.00 & 3.00 & 3.00 & 1.00 & 1.00 \\
\hline Jumlah & 2.27 & 14.00 & 14.00 & 14.00 & 6.00 & 6.00 \\
\hline
\end{tabular}

Langkah 2 : Lakukan normalisasi. Caranya dengan membagi setiap elemen dengan jumlah masing-masing kolom sepeti Tabel 2.3.

Tabel 2.3 Normalisasi Matrik

\begin{tabular}{|l|c|c|c|c|c|c|}
\hline Kriteria & K1 & K2 & K3 & K4 & K5 & K6 \\
\hline K1 & 0.44 & 0.36 & 0.36 & 0.36 & 0.50 & 0.50 \\
\hline K2 & 0.09 & 0.07 & 0.07 & 0.07 & 0.06 & 0.06 \\
\hline K3 & 0.09 & 0.07 & 0.07 & 0.07 & 0.06 & 0.06 \\
\hline K4 & 0.09 & 0.07 & 0.07 & 0.07 & 0.06 & 0.06 \\
\hline K5 & 0.15 & 0.21 & 0.21 & 0.21 & 0.17 & 0.17 \\
\hline K6 & 0.15 & 0.21 & 0.21 & 0.21 & 0.17 & 0.17 \\
\hline
\end{tabular}

Langkah 3: Cari rata-rata setiap kriteria. Caranya, jumlahkan tiap baris kemudian dibagi dengan jumlah kriteria yang ada sepeti Tabel 2.4

\section{Tabel 2.4 Rata-Rata Kriteria}

\begin{tabular}{|c|r|r|r|r|r|r|r|r|}
\hline $\begin{array}{c}\text { Kriteri } \\
\mathrm{a}\end{array}$ & $\mathrm{K} 1$ & $\mathrm{~K} 2$ & $\mathrm{~K} 3$ & $\mathrm{~K} 4$ & $\mathrm{~K} 5$ & $\mathrm{~K} 6$ & $\begin{array}{c}\text { Jumla } \\
\mathrm{h}\end{array}$ & $\begin{array}{c}\text { Rata } \\
\text {-rata }\end{array}$ \\
\hline $\mathrm{K} 1$ & 0.4 & 0.3 & 0.3 & 0.3 & 0.5 & 0.5 & & \\
& 4 & 6 & 6 & 6 & 0 & 0 & 2.51 & 0.42 \\
\hline $\mathrm{K} 2$ & 0.0 & 0.0 & 0.0 & 0.0 & 0.0 & 0.0 & & \\
& 9 & 7 & 7 & 7 & 6 & 6 & 0.41 & 0.07 \\
\hline $\mathrm{K} 3$ & 0.0 & 0.0 & 0.0 & 0.0 & 0.0 & 0.0 & & \\
& 9 & 7 & 7 & 7 & 6 & 6 & 0.41 & 0.07 \\
\hline $\mathrm{K} 4$ & 0.0 & 0.0 & 0.0 & 0.0 & 0.0 & 0.0 & & \\
& 9 & 7 & 7 & 7 & 6 & 6 & 0.41 & 0.07 \\
\hline $\mathrm{K} 5$ & 0.1 & 0.2 & 0.2 & 0.2 & 0.1 & 0.1 & & \\
& 5 & 1 & 1 & 1 & 7 & 7 & 1.12 & 0.19 \\
\hline $\mathrm{K} 6$ & 0.1 & 0.2 & 0.2 & 0.2 & 0.1 & 0.1 & & \\
& 5 & 1 & 1 & 1 & 7 & 7 & 1.12 & 0.19 \\
\hline
\end{tabular}

Langkah 4: membuat matriks penjumlahan setiap baris.

Tabel 2.5 Tabel Matrik Penjumlahan Baris

\begin{tabular}{|l|c|c|c|c|c|c|r|}
\hline Kriteria & K1 & K2 & K3 & K4 & K5 & K6 & Jumlah \\
\hline K1 & 0.42 & 0.35 & 0.35 & 0.35 & 0.57 & 0.57 & 2.61 \\
\hline
\end{tabular}

JURSIMA

Jurnal Sistem Informasi dan Manajemen

\begin{tabular}{|l|l|l|l|l|l|l|l|}
\hline K2 & 0.08 & 0.07 & 0.07 & 0.07 & 0.06 & 0.06 & 0.42 \\
\hline K3 & 0.08 & 0.07 & 0.07 & 0.07 & 0.06 & 0.06 & 0.42 \\
\hline K4 & 0.08 & 0.07 & 0.07 & 0.07 & 0.06 & 0.06 & 0.42 \\
\hline K5 & 0.14 & 0.21 & 0.21 & 0.21 & 0.19 & 0.19 & 1.15 \\
\hline K6 & 0.14 & 0.21 & 0.21 & 0.21 & 0.19 & 0.19 & 1.15 \\
\hline
\end{tabular}

Langkah 5 : Perhitungan Ratio Konsistensi

Tabel 2.6 Matrik Ratio Konsistensi

\begin{tabular}{|l|l|c|c|c|}
\hline No. & Kriteria & Jumlah & Prioritas & Hasil \\
\hline 1 & Tahun Lulus & 2.61 & 0.42 & 3.03 \\
\hline 2 & Penghasilan Ortu & 0.42 & 0.07 & 0.49 \\
\hline 3 & Jumlah Saudara & 0.42 & 0.07 & 0.49 \\
\hline 4 & $\begin{array}{l}\text { Tanggungan Orang } \\
\text { Tua }\end{array}$ & 0.42 & 0.07 & 0.49 \\
\hline 5 & Pendidikan Orang tua & 1.15 & 0.19 & 1.34 \\
\hline 6 & Prestasi Akademik & 1.15 & 0.19 & 1.34 \\
\hline
\end{tabular}

Dari perhitungan diatas maka didapat hasil sebagai berikut:

Hasil $\quad: 7.18$

n $: 6$

Lambda Maks: 7.18/10

$\begin{array}{ll} & : 1.19 \\ \mathrm{CI}() & :(1.19-6) / 6 \\ \mathrm{CR}(\mathrm{CI} / \mathrm{IR}) & :-0.80 \\ & :-0.80 / 1.46 \\ & :-0.54\end{array}$

Kesimpulan : Karena CR $<0.1$ maka ratio konsistensi dari perhitungan diatas dapat bisa diterima.

\section{B. Menentukan Prioritas Subkriteria}

Langkah 1: Membuat matriks nilai cerita

Tabel 2.7 Prioritas Kriteria

\begin{tabular}{|c|c|c|c|}
\hline & Baik & Sedang & Buruk \\
\hline Baik & 1 & 2 & 5 \\
\hline Sedang & 0.5 & 1 & 2 \\
\hline Buruk & 1.67 & 3.5 & 1 \\
\hline
\end{tabular}

Tabel 2.8 Matrik Nilai

\begin{tabular}{|c|c|c|c|c|c|c|}
\hline & Baik & Sedang & Buruk & $\sum$ baris & Prioritas & $\begin{array}{c}\text { Prioritas } \\
\text { Subkriteria }\end{array}$ \\
\hline Baik & 0.60 & 0.57 & 0.67 & 1.84 & 0.61 & 1 \\
\hline Sedang & 0.30 & 0.29 & 0.22 & 0.81 & 0.27 & 0.44 \\
\hline
\end{tabular}

https://ejournal.stmikgici.ac.id/ STMIK GICI 


\begin{tabular}{|c|c|c|c|c|c|c|}
\hline Buruk & 0.10 & 0.14 & 0.11 & 0.36 & 0.12 & 0.19 \\
\hline
\end{tabular}

Langkah 2 :Matriks penjumlahan tiaptiap baris

\section{Tabel 2.9 Matrik Penjumlahan Setiap Baris}

\begin{tabular}{|l|l|l|l|l|}
\hline & Baik & Sedang & Buruk & Jumlah \\
\hline Baik & 0.61 & 0.54 & 0.71 & 1.86 \\
\hline Sedang & 0.31 & 0.27 & 0.24 & 1.86 \\
\hline Buruk & 0.10 & 0.13 & 0.12 & 0.36 \\
\hline
\end{tabular}

Langkah 3 :Perhitungan rasio konsistensi

Tabel 2.10 Ratio Konsistensi Sub Kriteria

\begin{tabular}{|l|l|l|l|}
\hline & $\begin{array}{c}\text { Jumlah } \\
\text { per baris }\end{array}$ & Prioritas & Hasil \\
\hline Baik & 1.86 & 0.61 & 2.47 \\
\hline Sedang & 0.81 & 0.27 & 1.08 \\
\hline Buruk & 0.36 & 0.12 & 0.48 \\
\hline
\end{tabular}

\section{Menentukan Hasil Akhir}

Pada SMA Negeri 12 Padang dapat diambil beberap sampel data yaitu seperti pada Tabel 2.11

Tabel 2.11 Hasil Prioritas

\begin{tabular}{|l|l|l|l|l|l|l|}
\hline & $\mathrm{k} 1$ & $\mathrm{k} 2$ & $\mathrm{k} 3$ & $\mathrm{k} 4$ & $\mathrm{k} 5$ & $\mathrm{k} 6$ \\
\hline Prioritas & 0.42 & 0.7 & 0.7 & 0.7 & 0.19 & 0.19 \\
\hline Sub1 & 0.61 & 0.61 & 0.61 & 0.61 & 0.61 & 0.61 \\
\hline sub2 & 0.27 & 0.27 & 0.27 & 0.27 & 0.27 & 0.27 \\
\hline sub3 & 0.12 & 0.12 & 0.12 & 0.12 & 0.12 & 0.12 \\
\hline
\end{tabular}

Tabel 2.12 Hasil Proses AHP

\begin{tabular}{|l|l|l|l|l|l|l|l|}
\hline & K1 & K2 & K3 & K4 & K5 & K6 & Total \\
\hline A & 0.072 & 0.04 & 0.09 & 0.65 & 0.13 & 0.13 & 1.112 \\
\hline B & 0.032 & 0.16 & 0.65 & 0.65 & 0.29 & 0.29 & 2.072 \\
\hline C & 0.016 & 0.04 & 0.09 & 0.09 & 0.13 & 0.13 & 0.496 \\
\hline D & 0.072 & 0.16 & 0.65 & 0.09 & 0.29 & 0.29 & 1.552 \\
\hline
\end{tabular}

\section{HASIL DAN PEMBAHASAN}

Implementasi sistem adalah sistem yang siap pakai untuk diterapkan pada sebuah perusahaan yang telah diteliti.Sebelum diimplementasikan secara langsung pada perusahaan, perlu dilakukan pengujian terlebih dahulu apakah sistem sudah berjalan dengan benar serta juga merupakan uji coba langsung cara menjalankan sistem bagi pengguna

\section{A. Form Entry Alternative}

Form Ini berguna untuk mendata seluruh alternative. Terdapat tombol Simpan/ Ubah, berguna dalam menyimpan data ke database dan memperbaharui data dalam database, serta tombol keluar untuk keluar.Untuk menginputkan data alternative klik entri alternative pada menu, danisi data criteria seperti Gambar 3.1

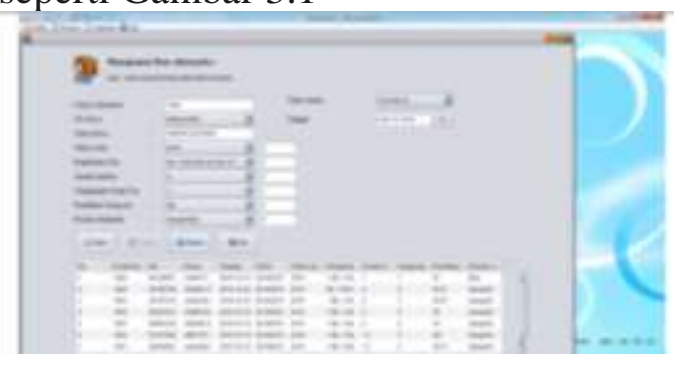

Gambar 3.1 Form Entri Alternative

\section{B. Laporan Hasil Proses AHP}

Form Ini berguna untuk mendata seluruh proses AHP. Terdapat tombol Simpan/ Ubah, berguna dalam menyimpan data ke database dan memperbaharui data dalam database, serta tombol keluar untuk keluar.Untuk menginputkan data proses AHP klik proses AHP pada menu, danisi data criteriasepertiGambar 3.2 


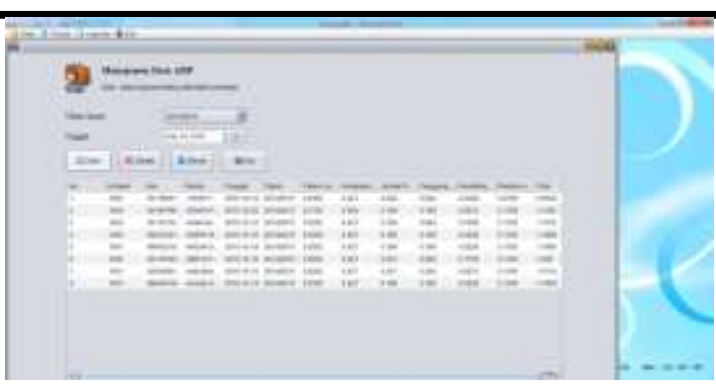

Gambar 3.2 Laporan Hasil Proses AHP

\section{Laporan Hasil Proses Penilaian Calon Peserta Bidikmisi}

Untuk menampilkan dan mencetak Laporan Hasil Proses Penilaian Calon Peserta Bidik misi maka dapat dilakukan dengan cara klik menu Laporan dan kemudian pilih Laporan Hasil Proses Penilaian Calon Peserta Bidikmisi lalu kita diminta untuk menginputkan nama Kepala Sekolah dan Tahun Ajaran kemudian akan tampil Laporan Hasil Proses Penilaian Calon Peserta Bidikmisi seperti Gambar 3.3

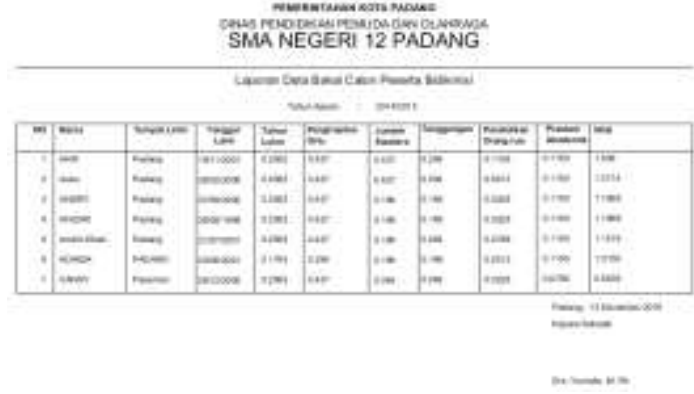

\section{Gambar 3.3 Laporan Hasil Proses Penilaian}

\section{SIMPULAN}

Berdasarkan atas penelitian yang telah penulis lakukan pada SMA Negeri 12 Padang, maka dapat diambil kesimpulan sebagai berikut :

1. Aplikasi sistem pendukung keputusan dapat membantu pihak sekolah dalam menentukan siswa yang berhak mengikuti program bidikmisi dengan hasil keputusan yang mutlak.

2. Penerapan metode Analytical Hierarchy Process dapat membantu dalam menghasilkan peserta bidikmisi yang mempunyai kemampuan dari masing-masing mata pelajaran sesuai kriteria dalam penyeleksian.

3. Aplikasi sistem pendukung keptusan dapat membantu pihak sekolah dalam menghasilkan siswa yang berkompeten dan berhak dalam menerima bidikmisi..

4. Aplikasi yang dirancang menggunakan database MySQL dan bahasa pemrograman JAVA.

\section{UCAPAN TERIMA KASIH}

Penulis sampaikan ucapan terima kasih kepada semua pihak yang terlibat sehingga penelitian ini bisa berjalan dengan lancar, baik dan sesuai dengan yang diharapkan.

\section{DAFTAR PUSTAKA}

Aldo, D. (2019). Pemilihan Bibit Lele Unggul dengan Menggunakan Metode Weighted Product. Jurnal Teknologi dan Open Source, 2(1), 1523.

A.S., Rosa dan Shalahuddin, M. 2013. Rekayasa Perangkat Lunak Terstruktur Dan Berorientasi Objek. Bandung: Informatika Bandung.

Eka Iswandy. 2015. "Sistem Penunjang Keputusan Untuk Menentukan Penerimaan Dana Santunan Sosial Anak Nagari Dan Penyalurannya Bagi Mahasiswa Dan Pelajar Kurang Mampu Di Kenagarian BarungBarung Balantai Timur". Jurnal Teknoif Vol.3 No.2, Oktober 2015.

Eko Darmanto. 2014. "Penerapan Metode AHP (Analythic Hierarchy Process) Untuk Menetukan Kualitas Gula https://ejournal.stmikgici.ac.id/ STMIK GICI 


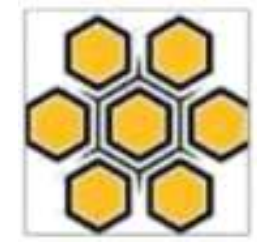

Tumbu". Jurnal SIMETRIS Vol.5 No.1, April 2014.

Hetty Rohayani. 2013. "Analisis Sistem Pendukung Keputusan Dalam Memilih Program Studi Menggunakan Metode Logika Fuzzy". Jurnal Sistem Informasi Vol.5 No.1, April 2013

Kusrini. 2007. Konsep dan Aplikasi Sistem Pendukung Keputusan. Yogyakarta: C.V Andi Offset.

Raharjo, Budi. 2011. Belajar Otodidak Membuat Database Menggunakan MySQL. Bandung: Informatika Bandung.

Sri Eniyati. 2011. "Perancangan Sistem Pendukung Pengambilan Keputusan Untuk Penerimaan Beasiswa Dengan
Metode SAW". Jurnal Teknologi Informasi DINAMIK Vol.16 No.2, Juli 2011.

Sianipar. 2013. Java, Teori, Algoritma dan Aplikasi. Yogyakarta: C.V Andi Offset.

Tohari, Hamim. 2014. Analisis Serta Perancangan Sistem Informasi Melalui Pendekatan UML. Yogyakarta: C.V Andi Offset.

Yeremia Yuliawan. 2013. "Pengembangan Sistem Informasi Pendataan Jemaat Gereja Masehi Advent Hari Ketujuh Konferens Jawa Kawasan Timur Berbasis Web". Jurnal JSIKA Vol.2 No.2, 2013. 